\title{
POSSIBLE MATERIALS AND PRODUCTION TECHNOLOGIES FOR A SPECIAL PURPOSE HELICAL TORSION SPRING

\author{
G. Németh
}

University of Miskolc, Egyetemváros, 3515, Miskolc, Hungary, e-mail: machng@uni-miskolc.hu

\begin{abstract}
There are a huge number of ideas at the area of traction drives and also at that of the epicyclic or by other words, planetary drives. The majority of these designs, contain solely rigid wheels, and the contact forces that are proportional to the transmitted torque are produced by separate clamping devices. The author introduced an innovative design, which integrates some elements with merging functions. A part of the contacting rollers are elastic ones and their shape assures the requirement of uniform strength. The curiosities of the elastic rollers are their shapes. Observing both their shapes and loads, they are helical torsion springs. They can be made of pure metals and composites, so of spring steel and also from fiber-reinforced plastics. There is a wide range of production technology considered depending on individual or mass production. The author has received some ideas from the areas of helical spring bearings, the machined torsion springs and the fiber-reinforced tubes. He also find a method to coil helical torsion spring of uniform strength from sheet metal, making the pre-manufactured "wire" of changing width by laser cutting, and to cut tubes by spark cutting.
\end{abstract}

Keywords: helical torsion spring, sheet metal, tube, laser cutting, spark cutting, fibre-reinforced palstic

\section{INTRODUCTION}

The epicyclic gear drive is a commonly used drive both for reducing and increasing speed with high efficiency. They are able to transmit power with high power density. The rigidity of the elements of the drive is usually high, but there are applications with elastic elements too. There are applications where some disadvantage should be avoided. These are the relatively high production costs, the large noise in multiplication service, the sensitivity of the drive for the lubrication and the required production accuracy considering the gears and bearings.

There are applications, where some points of views are not so important, as that of the others. When the accurate transmission ratio or the extremely high power density is not required, epicyclic traction drive can be applied. There are many areas where the simplicity, the low noise level and the price are more important. Epicyclic traction drives are used in many fields, including the tinny drives of human prosthesis and the drives of infinitely changing transmission ratios.

One of the problems of traction drives is the efficiency, though the influencing factors can be eliminated.

- Traction fluid enables greater allowable contact stress, without the danger of seizure (scuffing) of the hardened steel surfaces.

- The geometric slip can be also avoided by the proper geometry of the contacting surfaces.

- The traction drives are force closing, so they require tensioning. The tensioning device should produce a compressive force that is proportional to the transmitting load. This device makes the drive more complicated.

- Merging the functions seems to be a proper method for simplifying the design.

An epicyclic traction drive which avoids geometrical slip, can be so efficient as that of the gear drive.

The materials of the basic elements of the drive depend on their function and the necessary power density. The necessity of lubricant is influenced by the amount of dissipated heat. The quality of lubricant (when required any) depends on the types of contacting surfaces. A pair of materials, which tends not to adhesion, and there is no danger for overheating, needs not any lubricant.

The selected type of epicyclic drive that we should analysed is a simple one with single inner and single outer connection and designated as io type drive, is shown in Fig. 1. The usual transmission ratio range is shown in Fig 2.

Our idea is an epicyclic traction drive with elastic elements [5]. Some of the elements are helical torsion springs, as the Fig. 3 shows. The planet wheel, 2 can be rigid and self aligning in relation to the planet carrier. The drive is unidirectional. It means that the drive can transmit power only at one sense of rotation. The springs include both the function of traction wheel and the clamping device. The opposite sense of rotation results a zero output power, so it works in an overrunning clutch service. 


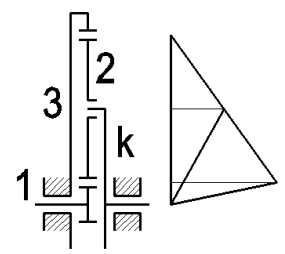

Figure 1. Kinematical model and speed diagram of an io type epicyclic drive

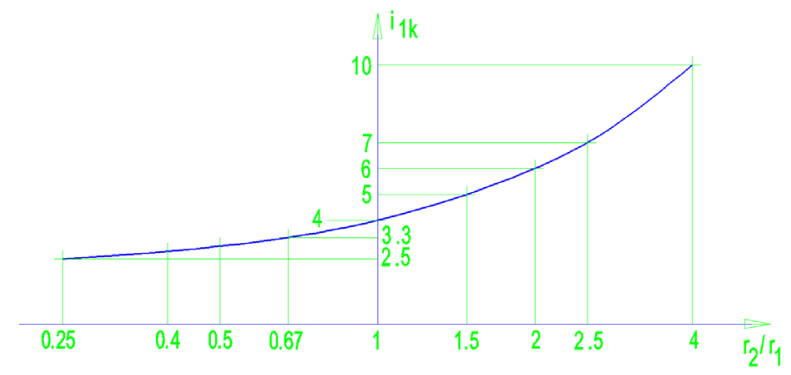

Figure 2. Transmission ratio range of an io type epicyclic drive

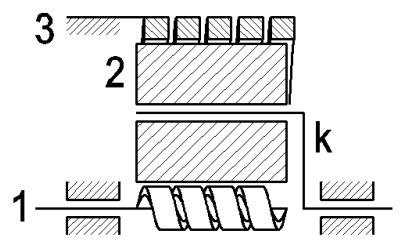

Figure 3. Epicyclic drive with elastic elements

\section{THE SHAPE OF THE SPRING}

The shape of the spring has got a large variability. The width of strip (and also the lead angle) is constant or changing. On the base of the number of starts, the thread is single or double, and the lead direction along the spring is the same or variable. The most promising shape of springs, both for the sun wheel, 1 and the annular wheel, 3 are shown in Fig. 4 and Fig. 5. Both springs are driven or fixed in the middle of their length. The imagining row material, type of half ready product and type of production method has got a large variability.

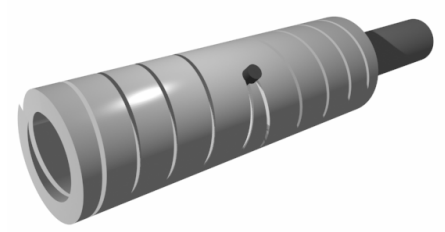

Figure 4. Spatial modes of a single thread spring with changing lead direction and changing strip width

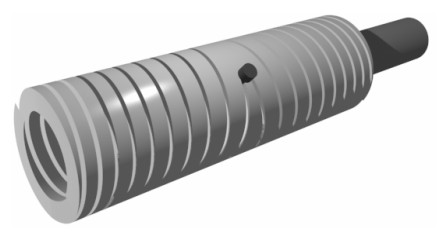

Figure 5. Spatial modes of a double thread spring with changing lead direction and changing strip width 


\section{MATERIALS}

The usual materials for the basic elements of traction drives are the metals or in special cases they are covered by rubber like plastics. The usual spring materials are the metal alloys, the plastics and the composites.

The material and the shape of the spring influence characteristics. A greater output load (torque) requires a greater pressure between the contacting wheels. A spring with linear characteristics facilitates the self adjustment of the clamping force.

On the other hand, the shape of a spring and the material together influence the hysteresis of the springs. A large hysteresis can be useful in special applications, like in the suspension of an aeroplane, where annular springs can absorb the large impact energy of landing. In our problem, at the initial transient phenomenon of the starting process, it seems to be useful to absorb the energy of oscillation.

The shape of the springs is fixed, it is a helical torsion spring. Its load is bending, and the changing width can result a balanced design due to the bending stress.

A natural requirement against the spring material is the high modulus of elasticity. The spring steels can fulfil this constraint, and there are also some other alloys with similar properties. For a power transmission, the great yield strength and the large allowable contact stress are also advantageous. When the materials of the contacting elements are sensitive for adhesion, they should be separated by a suitable machine element that is the lubricant, having proper viscosity and rheopectic behaviour.

\section{TECHNOLOGIES FOR PRODUCTION}

Nowadays the contacting elements of traction drives are mainly made of steel, especially rolling bearing steel. Sometimes a part of the rollers are standard ball bearing, as it is true for the real particle of the epicyclic traction drive whose kinematical outline is shown by Fig. 6 . In this design the planet rollers, 2 are ball bearings. The real cone angle is much less, as it shown. The sun roller and the ring roller is conical, the tensioning force is constant, made by a helical compression spring, through a standard ball bearing.

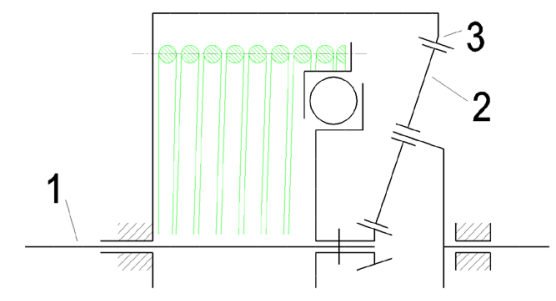

Figure 6. Epicyclic drive with standard planet rollers [7]

Considering the drive in Fig. 3, and the suggested shape of sun and ring rollers, the planet rollers can not be simple ball bearings, but suggested to be made of roller bearing steel. The springs shown in Fig. 4 and Fig. 5 are imagined to be made of spring steel. The pre-product can be sheet metal or tube. Fig. 7 shows the plan of the laser cutting for a double thread helical spring. A winding process should form the final shape of the spring, The diameters should be greater at the sides, to assure an initial tensioning. Modifying the laser cutting plan, an equally stressed shape is obtained, as Fig. 8 shows.
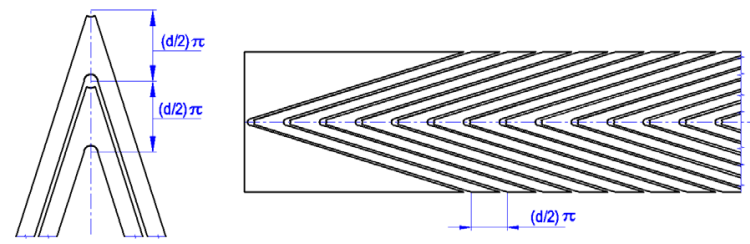

Figure 7. Laser cutting of a sheet metal for a special double thread spring 
When the preproduct is hollow cylinder, turning, milling or spark cutting is the possible production technology.

Considering the laser cutting plan of the sheet metal in Fig. 8, the knitting pattern of glass fiber could be the same. Designing the tool for the injection moulding, the mass production of these highly elastic elements would be fulfilled. In this case lubricant is not needed, but the necessity of cooling by air or water should be further investigated.
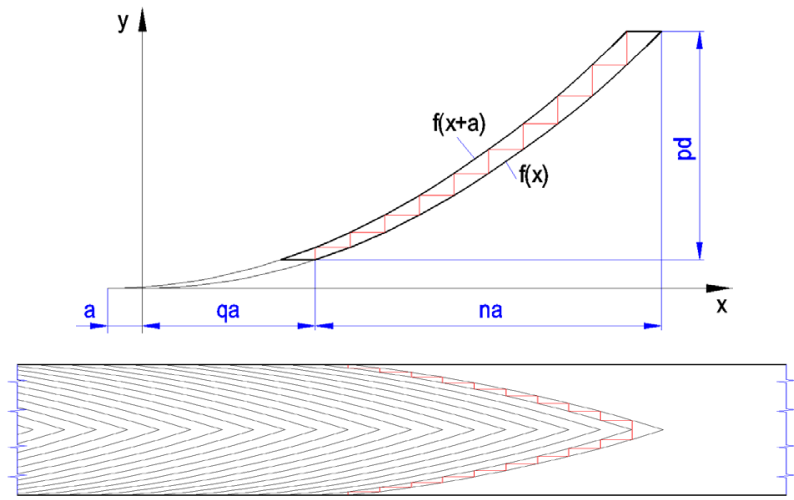

Figure 8. Mathematical formulation of the equally stressed shape - varying ribbon width

The moulding is also a suitable technology for mass production of fibre reinforced plastics parts. Fig. 9 and 10 show the forming of tool and the removal of the ready made part for a single thread spring with changing lead direction and constant strip width.

The core die made of two identical parts, the cavity die made of one piece. After finishing the moulding process the core dies can be driven out like bolts, and the plastic part can be pulled out of the cavity die, due to the elasticity of the workpiece. This part is a spring with smooth and burr-free outer surface and perfectly suitable for a sun gear of a low power epicyclic drive. The tapering of the sun roller (and also that of the annular roller) is useful for initial tensioning of the friction drive.

By similar manner, the tool for the annular wheel of the drive can be designed. The only differences are, the cavity die contains the thread and it is split, but the core dye is undivided. The inner surface of the annular spring is smooth and burr-free.
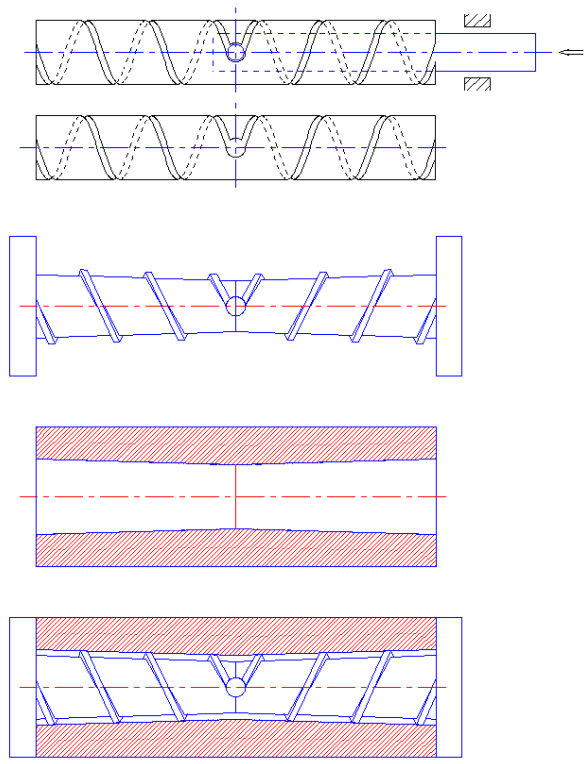

Figure 9. Sun roller and its dies - core dies, cavity die and the tool after assembly 


\section{CONCLUSION}

An epicyclic traction drive with special spring elements was introduced by the author. Using spring steel for the most sensitive sun and ring rollers, the dependency of production technology on the pre-product was also visualized. The author also projected a possible composite material with its technology for the spring elements, naturally for a fully different application with a fully different lubricating and cooling system.

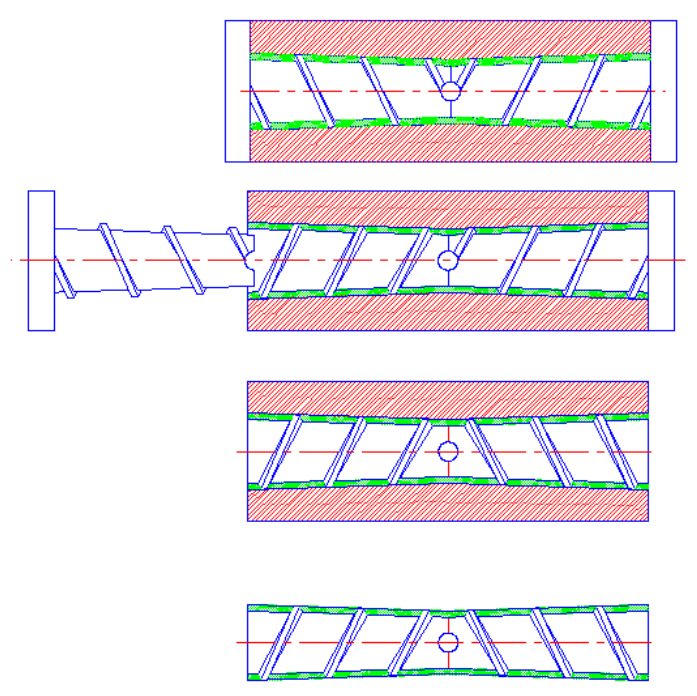

Figure10. The die after moulding and the removal of the ready made part (The inlet is not shown.)

\section{ACKNOWLEDGEMENT}

„A cikkben/előadásban/tanulmányban ismertetett kutató munka a TÁMOP-4.2.1.B-10/2/KONV2010-0001 projekt eredményeire alapozva a TÁMOP-4.1.1.C-12/1/KONV-2012-0002 jelü projekt részeként - az Új Széchenyi Terv keretében - az Európai Unió támogatásával, az Európai Szociális Alap társfinanszírozásával valósult meg."

„The research work presented in this paper/study/etc. based on the results achieved within the TÁMOP-4.2.1.B-10/2/KONV-2010-0001 project and carried out as part of the TÁMOP-4.1.1.C12/1/KONV-2012-0002 project in the framework of the New Széchenyi Plan. The realization of this project is supported by the European Union, and co-financed by the European Social Fund."

\section{REFERENCES}

[1] Németh Géza , Péter József , Németh Nándor, A new type of epicyclic traction drive, ADVANCES IN MECHANICAL ENGINEERING 1:(1) pp. 137-142. (2013), 1st INTERNATIONAL SCIENTIFIC CONFERENCE ON ADVANCES IN MECHANICAL ENGINEERING. Debrecen, Magyarország: 2013.10.10 -2013.10.11. (ISBN 978-963-473-623-3)

[2] Németh Géza, Péter József, Döbröczöni Ádám, Németh Nándor, (2012) Helical Torsion Spring Improvement for Epicyclic Traction Drive in GÉP, LXIII (12): 85-88.

[3] Németh Géza, Péter József, Döbröczöni Ádám (2012) Helical Springs in Epicyclic Traction Drives in DESIGN OF MACHINES AND STRUCTURES, 2(2): 81-92.

[4] Németh Géza, Péter József, Döbröczöni Ádám (2012) Ensuring the Clamping Force in Epicyclic Traction Drive by a New Sun Wheel Design in DESIGN OF MACHINES AND STRUCTURES 2(2): 93-100.

[5] Németh Géza , Péter József, Döbröczöni Ádám , Helical Springs in Epicyclic traction drives (in Hungarian) Csavarrugó alkalmazása dörzsbolygóműben: In: Csibi Vencel (szerk.), OGÉT 2012, XX. Nemzetközi Gépészeti Találkozó . Konferencia helye, ideje: Kolozsvár , Románia , 
2012.04.19 -2012.04.22. Kolozsvár: Erdélyi Magyar Müszaki Tudományos Társaság, 2012. pp. 327-330.

[6] Németh Géza , Péter József, Continuously Variable Epicyclic Traction Drive, In: Boris Obsieger (szerk.), CADAM 2011: 9th International Scientific Conference on Advanced Engineering, Computer Aided Design and Manufacturing .,Vela Luka , Croatia , 2011.09.20 -2011.09.24. Rijeka: University of Rijeka, 2011. pp. 35-36. , (ISBN:978-953-7142-58-2)

[7] Horvath, E. inventor, Otto Bock Orthopadische Industrie Besitz-Und Werwaltungs-KG, Assignee, Planetary Friction Drive, U.S. Patent 5, 046,996, filed Jul. 18, 1989, and issued Sep. 10, 1991. 